\title{
ANALISIS DISTRIBUSI SUHU DAN KELEMBABAN UDARA DALAM RUMAH JAMUR (KUMBUNG) MENGGUNAKAN COMPUTATIONAL FLUID DYNAMICS (CFD)
}

\author{
Analysis of the Temperature Distribution and Air Humidity in Mushroom House Using \\ Computational Fluid Dynamics (CFD) \\ Anisum ${ }^{1,2}$, Nursigit Bintoro', Sunarto Goenadi' ${ }^{1}$ \\ ${ }^{1}$ Jurusan Teknik Pertanian, Fakultas Teknologi Pertanian, Universitas Gadjah Mada, \\ Jl. Flora No. 1, Bulaksumur, Yogyakarta 55281 \\ ${ }^{2}$ Sekolah Tinggi Pertanian Kutai Timur, Jl. Soekarno Hatta No. 1, Sangatta, Kutai Timur, Kalimantan Timur 75387 \\ Email: stiper_kutim@yahoo.com
}

\begin{abstract}
ABSTRAK
Salah satu upaya untuk mengoptimalkan suhu dan kelembaban udara dalam rumah jamur pada musim kemarau dengan menggunakan evaporative cooler (pendingin penguap). Pada penelitian ini ada dua variasi perlakuan yang dikaji pendistribusian suhu dan kelembaban udara dalam rumah jamur dengan menggunakan Computational Fluid Dynamics (CFD), yaitu kondisi bangunan menggunakan ventilasi alamiah dan kondisi bangunan dengan pendingin penguap (evaporative cooler) menggunakan air. Analisis dengan Computational Fluid Dynamics (CFD) mampu memodelkan distribusi suhu dan kelembaban udara, serta pola pergerakan udara dalam rumah jamur. Nilai validasi distribusi suhu dan kelembaban udara dalam rumah jamur menunjukkan error $0,70-2,62 \%$. Dari hasil analisis CFD suhu dan kelembaban udara mampu diturunkan sebesar $\pm 1^{\circ} \mathrm{C}$ dan $\pm 5,1 \%$ untuk bangunan dengan evaporative cooler menggunakan air. Hal ini menunjukkan bahwa bangunan dengan evaporative cooler menggunakan air mampu menurunkan suhu udara dan meningkatkan kelembaban udara dalam rumah jamur.
\end{abstract}

Kata kunci: Computational Fluid Dynamics (CFD), rumah jamur (kumbung), evaporative cooler

\begin{abstract}
One effort to optimize the temperature and humidity in the mushroom house during the dry season using evaporative cooler. This research was conducted two treatment variation which were assessed about distribution of temperature and humidity of air inside a mushroom house using Computational Fluid Dynamics (CFD) is the condition of building using natural ventilation and condition of building with water used evaporative cooler. Computational Fluid Dynamics (CFD) analysis was able to model the distributions of temperature and humidity, and air movement pattern inside of a mushroom house. The validation point of temperature distribution and humidity in the mushroom house has an error $0.70-2.62 \%$. The results CFD analysis of temperature and humidity were able to reduced by about $\pm 1^{\circ} \mathrm{C}$ and $\pm 5.1 \%$ for building with evaporative cooler used water. The indicated that buildings evaporative cooler used water able to reduced air temperature and increasing humidity in the mushroom houses.
\end{abstract}

Keywords: Computational Fluid Dynamics (CFD), oyster, mushroom house, evaporative cooler

\section{PENDAHULUAN}

Jamur memiliki kelebihan dibandingkan dengan bahan makanan lainnya, yaitu gizinya yang tinggi dan cita rasanya yang lezat (Agromedia, 2009). Jamur tiram merupakan salah satu produk komersial dan dapat dikembangkan dengan teknik sederhana (Zervakis dan Balis, 1996 dalam Kibar dan Peksen, 2008). Dalam budidaya jamur tiram sangat dipengaruhi oleh beberapa faktor lingkungan, misalnya suhu, kelembaban, cahaya, dan konsentrasi $\mathrm{CO}_{2}$. Namun, suhu adalah faktor lingkungan yang paling dominan (Chang dan Miles, 1989 dalam Han dkk., 2009). Suhu udara dan kelembaban relatif $(\mathrm{RH})$ adalah dua parameter lingkungan yang berpengaruh terhadap pertumbuhan tanaman (Hanan dkk., 1978 dalam Romdhonah, 2011). Pada musim penghujan pertumbuhan jamur sangat baik karena suhunya rendah, namun pada musim 
kemarau pertumbuhan jamur terhambat karena kelembaban rendah dan suhu udara tinggi. Cahyana dkk. (2007) dalam Yanuati (2007) menjelaskan pada umumnya, jamur tiram bisa tumbuh pada suhu $24-28^{\circ} \mathrm{C}$. Salah satu upaya untuk mengoptimalkan suhu dan kelembaban udara dalam rumah jamur dengan menggunakan evaporative cooler (pendingin penguap). Dengan menggunakan evaporative cooler dalam rumah jamur, tidak menjamin pertumbuhan jamur yang baik dan seragam (tumbuh merata), kecuali udara didistribusikan merata di atas media tanam jamur (baglog). Kekhawatiran ini menyebabkan tuntutan perlunya menganalisis sifat dan pola aliran udara dalam rumah jamur. Pemecahan analisis aliran udara dalam rumah jamur dapat dilakukan dengan Computational Fluid Dynamics (CFD) (Versteeg dan Malalasekera, 1995). Penelitian ini bertujuan untuk menganalisis distribusi suhu dan kelembaban udara pada rumah jamur dengan dua variasi perlakuan, yaitu kondisi bangunan tanpa bantuan alat mekanis (ventilasi alamiah) dan kondisi bangunan dengan pendingin penguap (evaporative cooler) menggunakan air, serta melakukan validasi antara hasil pengukuran dengan perhitungan hasil Computational Fluid Dynamics (CFD).

\section{METODE PENELITIAN}

\section{Waktu dan Tempat}

Penelitian dilaksanakan pada bulan Maret sampai Mei 2014 berlokasi di Fakultas Teknologi Pertanian, Universitas Gadjah Mada, Yogyakarta.

\section{Bahan dan Alat}

Bahan yang digunakan dalam penelitian terdiri dari rumah jamur (kumbung) dengan dimensi 3 x 2 × 3 m, rakrak dan baglog (media tanam jamur). Rumah jamur terbuat dari anyaman bambu (gedek), baik untuk atap maupun dinding, sedangkan rangka rumah menggunakan bambu dan lantai dari concrete block hollow. Peralatan yang digunakan yaitu evaporative cooler, data logger, thermohygrometer, anemometer, termometer, termokopel dan seperangkat laptop dengan software Gambit 2.4.6 dan Fluent 6.3.

\section{Desain Bangunan}

Dalam penelitian ini, terdapat dua desain rumah jamur, yaitu bangunan kontrol (ventilasi alamiah) tanpa evaporative cooler dan bangunan dengan evaporative cooler (Gambar 1). Bangunan yang menggunakan evaporative cooler ini sama seperti bangunan konvensional hanya saja pada salah satu sisinya menggunakan evaporative cooler. Di belakang pad diletakkan kipas angin dengan ukuran diameter $38 \mathrm{~cm}$ dan 60 watt (Gambar 1d).
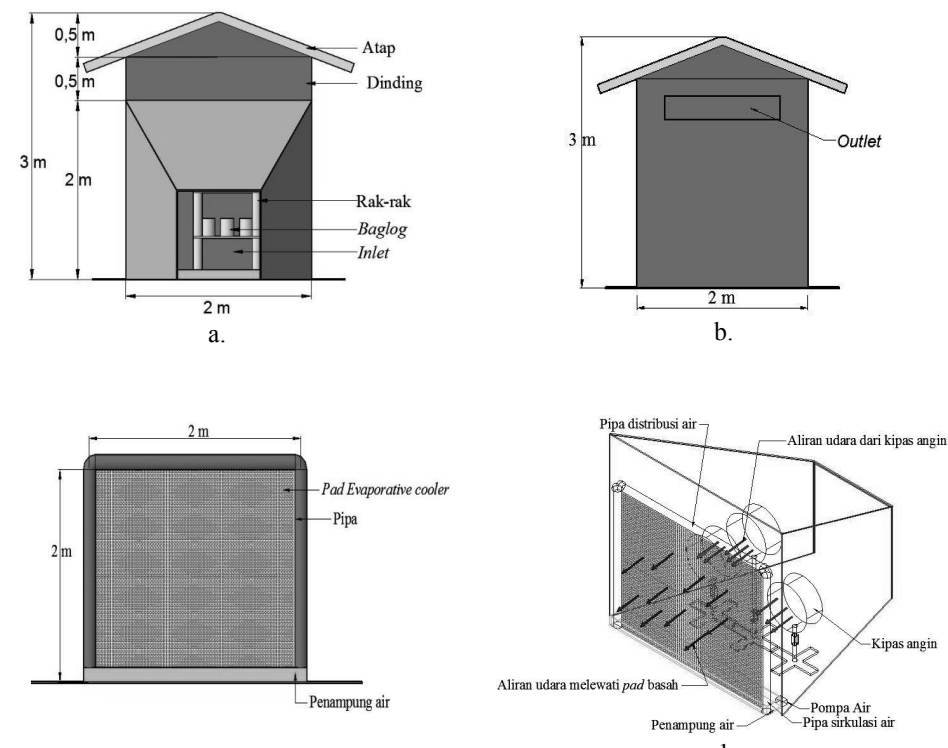

c.

d.

Gambar 1. Desain rumah jamur:
a. Bangunan kontrol tampak depan (inlet)
b. Bangunan tampak belakang (outlet)
c. Desain evaporative pad
d. Skematis dari sistem evaporative cooling

\section{Analisis Data Menggunakan Computational Fluid Dynamics (CFD)}

Dalam simulasi pola aliran udara, udara digambarkan secara kuantitatif dalam besaran suhu dan kecepatan dengan bentuk persamaan differensial, dalam koordinat kartesian dan dipecahkan dengan teknik CFD (tiga dimensi) berdasarkan analisis numerik menggunakan metode volume hingga. Tiga persamaan atur aliran fluida yang menyatakan hukum kekekalan fisika (Versteeg dan Malalasekera, 1995), yaitu:

Persamaan kekekalan massa. Bentuk matematika untuk fluida yang tidak terkompresi dinyatakan pada

Persamaan 1:

$$
\frac{\partial(\rho u)}{\partial x}+\frac{\partial(\rho v)}{\partial y}+\frac{\partial(\rho w)}{\partial z}=0
$$

dimana $\rho$ adalah massa jenis fluida $\left(\mathrm{kg} / \mathrm{m}^{3}\right)$ dan $\mathrm{x}, \mathrm{y}, \mathrm{z}$ adalah koordinat kartesian.

Persamaan momentum. Persamaan momentum dikembangkan dari persamaan Navier-Stokes dalam bentuk sesuai dengan metode finite volume yang ditunjukkan pada Persamaan 2 sampai dengan Persamaan 4.

Momentum $x$ :

$$
\rho\left[u \frac{\partial u}{\partial x}+v \frac{\partial u}{\partial y}+w \frac{\partial u}{\partial z}\right]=\frac{\partial p}{\partial x}+\mu\left[\frac{\partial^{2} u}{\partial x^{2}}+\frac{\partial^{2} u}{\partial y^{2}}+\frac{\partial^{2} u}{\partial z^{2}}\right]+S_{M x}
$$


Momentum y:

$$
\rho\left[u \frac{\partial v}{\partial x}+v \frac{\partial v}{\partial y}+w \frac{\partial v}{\partial z}\right]=\frac{\partial p}{\partial y}+\mu\left[\frac{\partial^{2} v}{\partial x^{2}}+\frac{\partial^{2} v}{\partial y^{2}}+\frac{\partial^{2} v}{\partial z^{2}}\right]+S_{M Y}
$$

Momentum $z$ :

$$
\rho\left[u \frac{\partial w}{\partial x}+v \frac{\partial w}{\partial y}+w \frac{\partial w}{\partial z}\right]=\frac{\partial p}{\partial z}+\mu\left[\frac{\partial^{2} w}{\partial x^{2}}+\frac{\partial^{2} w}{\partial y^{2}}+\frac{\partial^{2} w}{\partial z^{2}}\right]+S_{M}
$$

dimana $\mu$ adalah viskositas dinamik fluida $(\mathrm{kg} / \mathrm{m}$ det) dan $S_{M X} S_{M Y} S_{M Z}$ adalah momentum yang berasal dari body per unit volume per unit waktu, masing-masing untuk koordinat $x, y$ dan $z$.

Persamaan energy. Persamaan energi diturunkan dari Hukum I Termodinamika. Secara matematika dinyatakan pada Persamaan 5.

$\rho\left[u \frac{\partial T}{\partial x}+v \frac{\partial T}{\partial y}+w \frac{\partial T}{\partial z}\right]=p\left[\frac{\partial u}{\partial x}+\frac{\partial v}{\partial y}+\frac{\partial w}{\partial z}\right]+k\left[\frac{\partial^{2} T}{\partial x^{2}}+\frac{\partial^{2} T}{\partial y^{2}}+\frac{\partial^{2} T}{\partial z^{2}}\right]+S_{i}$ $p$ adalah tekanan fluida $(\mathrm{Pa}), k$ adalah konduktivitas termal fluida $\left(\mathrm{W} / \mathrm{m}^{\circ} \mathrm{C}\right)$ dan $S i$ adalah energi yang ditambahkan per unit volume per unit waktu.

Dengan menggunakan persamaan-persamaan di atas, kondisi batas yang dijadikan input diolah dan dikembangkan menjadi suatu model dengan menggunakan software Fluent 6.3 sehingga diperoleh suatu output. Data input kondisi batas (boundary condition) dapat dilihat pada Tabel 1.

Pengaturan dasar pada Fluent 6.3 diawali dengan memilih pressure-based sebagai tipe solver, implicit sebagai formulation, absolute sebagai tipe velocity formulation dan steady sebagai tipe time, dan mengaktifkan model energi. Model k-epsilon digunakan pada penelitian ini karena model ini yang sering digunakan pada simulasi aliran fluida dan perpindahan panas. Model k-epsilon merupakan model

Tabel 1. Data input kondisi batas (boundary condition) untuk Fluent 6.3 pada bangunan kontrol dan bangunan dengan evaporative

\begin{tabular}{|c|c|c|c|c|c|c|c|}
\hline \multirow{2}{*}{ Uraian } & \multirow{2}{*}{ Satuan } & \multicolumn{3}{|c|}{ Bangunan kontrol } & \multicolumn{3}{|c|}{ Bangunan dengan evaporative cooler } \\
\hline & & $08.00 \mathrm{WIB}$ & $12.00 \mathrm{WIB}$ & $17.00 \mathrm{WIB}$ & $08.00 \mathrm{WIB}$ & $12.00 \mathrm{WIB}$ & $17.00 \mathrm{WIB}$ \\
\hline \multicolumn{8}{|l|}{ Inlet } \\
\hline Suhu udara & ${ }^{\circ} \mathrm{C}$ & 27,1 & 30,7 & 29,0 & 26,7 & 29,2 & 27,8 \\
\hline Kecepatan angin & $\mathrm{m} / \mathrm{det}$ & 0,3 & 0,3 & 0,3 & 0,4 & 0,4 & 0,4 \\
\hline \multicolumn{8}{|l|}{ Atap } \\
\hline Suhu udara & ${ }^{\circ} \mathrm{C}$ & 26,9 & 30,5 & 29,1 & 26,7 & 29,6 & 28 \\
\hline Koefisien pindah panas & $\mathrm{W} / \mathrm{m}^{2} . \mathrm{K}$ & 0,54 & 0,45 & 0,45 & 1,43 & 1,42 & 1,42 \\
\hline \multicolumn{8}{|l|}{ Dinding selatan } \\
\hline Suhu udara & ${ }^{\circ} \mathrm{C}$ & 27,3 & 31,1 & 29,5 & 26,9 & 30,5 & 28,3 \\
\hline Koefisien pindah panas & $\mathrm{W} / \mathrm{m}^{2} . \mathrm{K}$ & 0,88 & 1,43 & 0,99 & 1,43 & 1,42 & 1,42 \\
\hline \multicolumn{8}{|l|}{ Dinding utara } \\
\hline Suhu udara & ${ }^{\circ} \mathrm{C}$ & 27,4 & 30,9 & 29,9 & 27,8 & 31,3 & 29,2 \\
\hline Koefisien pindah panas & $\mathrm{W} / \mathrm{m}^{2} \cdot \mathrm{K}$ & 0,94 & 1,34 & 1,27 & 1,43 & 1,42 & 1,42 \\
\hline \multicolumn{8}{|l|}{ Lantai } \\
\hline Suhu udara & ${ }^{\circ} \mathrm{C}$ & 26,7 & 28,2 & 27,7 & 26,4 & 27,9 & 27.6 \\
\hline Koefisien pindah panas & $\mathrm{W} / \mathrm{m}^{2} . \mathrm{K}$ & 1,58 & 2,37 & 2,11 & 3,19 & 3,18 & 3,19 \\
\hline \multicolumn{8}{|l|}{ Rak I } \\
\hline Suhu udara di rak & ${ }^{\circ} \mathrm{C}$ & 27,2 & 30,3 & 29,4 & 27 & 29,8 & 28,8 \\
\hline Koefisien pindah panas baglog & $\mathrm{W} / \mathrm{m}^{2} . \mathrm{K}$ & 1,12 & 1,57 & 1,47 & 4,31 & 4,3 & 4,3 \\
\hline \multicolumn{8}{|l|}{ Rak II } \\
\hline Suhu udara di rak & ${ }^{\circ} \mathrm{C}$ & 27,1 & 29,8 & 29,3 & 27 & 29,3 & 28,7 \\
\hline Koefisien pindah panas baglog & $\mathrm{W} / \mathrm{m}^{2} . \mathrm{K}$ & 1,33 & 1,94 & 1,33 & 4,31 & 4,3 & 4,31 \\
\hline \multicolumn{8}{|l|}{ Rak III } \\
\hline Suhu udara di rak & ${ }^{\circ} \mathrm{C}$ & 26,8 & 29,4 & 28,7 & 26,5 & 28,8 & 28,1 \\
\hline Koefisien pindah panas baglog & $\mathrm{W} / \mathrm{m}^{2} . \mathrm{K}$ & 1,52 & 2,06 & 1,52 & 4,31 & 4,3 & 4,3 \\
\hline
\end{tabular}
cooler menggunakan air 
turbulensi yang cukup lengkap dengan dua persamaan yang memungkinkan kecepatan turbulen (turbulent velocity) dan skala panjang (length scales) ditentukan secara independen (Tuakia, 2008). Kacira dkk. (1998) dalam Han dkk. (2009) menyatakan bahwa analisis turbulensi pada aliran udara dalam rumah jamur dilakukan dengan model k-epsilon untuk memprediksi kecepatan distribusi udara. Persamaanpersamaan tersebut diselesaikan dengan metode iterasi (Patankar, 1980; Versteeg dan Malalasekera, 1995). Di dalam analisis menggunakan CFD, material penyusun rumah jamur (kumbung) seperti atap, dinding, lantai, rak-rak dianggap sebagai wall. Inlet dan outlet merupakan bukaan ventilasi rumah jamur. Adapun asumsi yang digunakan dalam analisis CFD adalah: 1) Udara bergerak dalam keadaan steady state dan tidak terkompresi (incompressible); 2) Udara lingkungan dianggap konstan selama simulasi; 3) Panas jenis, konduktivitas dan viskositas udara konstan. 4) Massa udara dalam rumah jamur tidak diperhitungkan; 5) Distribusi suhu udara pada tiap atap, dinding dan lantai rumah jamur seragam; 6) Dinding rumah jamur berupa anyaman bambu (gedek) dianggap tidak memiliki pori-pori atau dianggap rata; 7) Tanaman jamur tiram yang tumbuh tidak menghasilkan panas dan tidak menghambat pergerakan udara (tanaman jamur tidak didefinisikan).

\section{Validasi}

Besarnya error dalam validasi dihitung menggunakan Persamaan 6 (Yani, 2012) sebagai berikut:

$$
\operatorname{Error}(\%)=\frac{[\mathrm{p}-\mathrm{u}]}{\mathrm{p}} \times 100
$$

dimana $p$ adalah nilai suhu udara hasil CFD $\left({ }^{\circ} \mathrm{C}\right)$ dan $u$ adalah nilai suhu udara hasil pengukuran $\left({ }^{\circ} \mathrm{C}\right)$. Selain itu juga menggunakan paired samples t-test untuk melakukan perbandingan rataan antara output simulasi dan hasil observasi sistem nyata dengan asumsi bahwa variansi kedua sample sama (Pidd, 1992 dalam Singgih dan Susanto, 2006).

\section{HASIL DAN PEMBAHASAN}

\section{Hasil Analisis CFD pada Bangunan Kontrol}

Pada bangunan kontrol atau ventilasi alamiah suhu udara dalam rumah jamur berasal dari suhu udara lingkungan yang naik pada pagi hari sampai siang hari dan menurun kembali pada sore hari. Pada pukul 08:00 WIB, dari Gambar 2a dapat dilihat suhu udara dalam rumah jamur terdistribusi merata. Suhu udara rata-rata dalam rumah $\left(27^{\circ} \mathrm{C}\right)$ lebih rendah daripada suhu udara lingkungan $\left(27,1^{\circ} \mathrm{C}\right)$, karena radiasi matahari yang diterima atap dan konveksi panas dari material penyusun yang dihantarkan masih rendah. Kelembaban udara
(RH) rata-rata di dalam rumah jamur (90\%) lebih tinggi dari RH udara lingkungan $(88,37 \%)$ karena proses pemanasan dalam rumah jamur masih rendah sehingga uap air dalam bangunan belum banyak yang terbuang karena efek panas dan angin lingkungan. Pada Gambar 3a, suhu udara yang terendah berada di rak bawah berkisar $26,81^{\circ} \mathrm{C}-26,93^{\circ} \mathrm{C}$, sedangkan suhu udara paling tinggi di rak atas $\left(27,19^{\circ} \mathrm{C}\right)$.

Pada pukul 12:00, suhu udara dalam rumah lebih tinggi daripada suhu udara lingkungan $\left(30,7^{\circ} \mathrm{C}\right)$, sedangkan kelembaban udara rata-rata dalam rumah jamur $(76,06 \%)$ mendekati kelembaban udara lingkungan (76,26\%). Suhu udara paling tinggi di daerah atap $\left(30,9^{\circ} \mathrm{C}\right)$ dapat dilihat pada Gambar 2a. Tingginya suhu udara di dekat (bawah atap) karena atap merupakan material penyusun rumah jamur yang paling besar menerima radiasi matahari. Pada Gambar 3a, suhu udara terendah berada di rak bawah $\left(29,71^{\circ} \mathrm{C}-30,39^{\circ} \mathrm{C}\right)$.

Pada pukul 17:00, suhu udara rata-rata dalam rumah jamur $\left(29,07^{\circ} \mathrm{C}\right)$ lebih tinggi daripada suhu udara lingkungan $\left(29^{\circ} \mathrm{C}\right)$. Tingginya suhu udara pada sore hari karena terjadinya konveksi dalam rumah jamur dan panasnya terperangkap di material penyusun serta benda-benda (baglog) yang ada dalam rumah rumah jamur, sehingga menyebabkan kenaikan suhu udara. Dari Gambar 2a, suhu udara tertinggi berada di daerah atap. Tingginya suhu pada permukaan atap, disebabkan oleh model rumah jamur yang ada adalah jenis ventilasi dinding sehingga pada akhirnya suhu udara di atas dekat atap cenderung tinggi atau karena tidak adanya ventilasi di atap. Menurut Katsoulas dkk. (2006) dalam Suhardiyanto (2009), konfigurasi bukaan ventilasi yang paling efektif adalah kombinasi bukaan dinding dan atap, diikuti oleh bukaan dinding saja dan terakhir adalah bukaan atap saja. Adapun suhu udara terendah berada di rak bawah (dekat lantai) pada ketinggian kurang dari $2 \mathrm{~m}$ dapat dilihat pada Gambar 3a. Rendahnya suhu udara di rak bawah disebabkan udara lingkungan yang masuk melalui inlet pada permukaan lantai langsung menuju outlet (bukaan ventilasi dekat atap) dan akibat terhalang dinding $(2 \mathrm{~m})$ yang berada di bawah outlet, udara dibelokan kembali ke tengah dan terhalang oleh media tanam di rak bawah ketika diteruskan ke outlet, sehingga suhu udara di lantai dan di rak bawah lebih rendah dari rak atas dan rak tengah. Hal ini merupakan sifat dari udara yang akan membelokkan pola alirannya apabila mengenai suatu halangan yang tidak dapat dilewatinya. Pada pukul 17:00, RH udara rata-rata dalam rumah jamur $(79,96 \%)$ lebih rendah dari RH udara lingkungan $(80,47 \%)$ karena meningkatnya suhu udara dalam rumah jamur akibat panas yang dikonveksikan material penyusun rumah jamur dan benda-benda (baglog) yang berada di dalamnya.

Dengan kecepatan angin sebesar $0,3 \mathrm{~m} /$ detik, udara masuk dalam rumah jamur melalui bukaan inlet yang terletak di bagian bawah dinding dan keluar melalui outlet yang 
terletak di bagian atas dinding. Dalam hal ini, faktor termal berperan dominan karena kecepatan udara rendah sehingga terjadi pergerakan udara akibat perbedaan suhu dan kerapatan udara di dalam dan di luar rumah jamur atau disebut sebagai buoyancy effect. Kamaruddin (1999) dalam Suhardiyanto (2009) menyatakan bahwa batas kecepatan angin dimana faktor termal masih dapat berperan dominan sebesar $1 \mathrm{~m} / \mathrm{s}$.

\section{Hasil Analisis CFD pada Bangunan dengan Evaporative Cooler Menggunakan Air}

Pada analisis CFD, evaporative cooler sebagai inlet. Evaporative cooler menggunakan beberapa kipas dengan pad yang dibasahi air. Kipas tersebut meniupkan udara kering menuju pad yang dibasahi air dan udara kering tersebut menyentuh permukaan air yang kemudian diabsorbsi oleh udara sehingga udara akan mengandung uap air.

Pada pukul 08:00, suhu udara rata-rata dalam rumah jamur $\left(26,76^{\circ} \mathrm{C}\right)$ lebih rendah dari suhu udara lingkungan $\left(28,3^{\circ} \mathrm{C}\right)$ karena radiasi matahari yang diterima atap dan konveksi panas dari material penyusun yang dihantarkan masih rendah, selain itu juga adanya evaporative cooler yang mampu menurunkan suhu udara dan menaikan kelembaban udara. Pada Gambar 2b, suhu udara dalam rumah jamur memiliki kecenderungan meningkat dari posisi dekat lantai menuju posisi dekat atap karena panas matahari yang diterima atap dihantarkan ke dalam rumah jamur sehingga semakin dekat dengan atap suhu udara semakin tinggi. Masuknya udara dingin dari evaporative cooling menyebabkan RH udara rata-rata dalam rumah jamur 90,65\% lebih besar daripada $\mathrm{RH}$ udara lingkungan, yaitu 88,7\%. Dengan kecepatan angin 0,4 $\mathrm{m} /$ detik dari depan inlet dapat dilihat pada Gambar 3b, daerah yang lebih tinggi suhunya berada di rak atas dan rak tengah tempat di letakkannya media tanam jamur.

Pada pukul 12:00, suhu udara rata-rata dalam rumah jamur $29,29^{\circ} \mathrm{C}$ dan lebih rendah daripada suhu udara lingkungan $31,3^{\circ} \mathrm{C}$. Sebaliknya, RH udara dalam rumah jamur lebih tinggi $(80,96 \%)$ daripada $\mathrm{RH}$ udara lingkungan (75,94\%). Suhu udara tertinggi $30,15^{\circ} \mathrm{C}$ berada di atap, karena radiasi matahari yang langsung mengenai atap (Gambar $2 b$ ). Tingginya suhu bagian atap dengan kecepatan udara $0,4 \mathrm{~m} /$ detik, menyebabkan tekanan udara di sekitar atap meningkat, udara terdorong ke luar melalui bukaan outlet membawa udara panas di sekitar atap. Pada Gambar 3b, suhu terendah di rak bawah dan lantai berkisar $28,83^{\circ} \mathrm{C}-28,97^{\circ} \mathrm{C}$.

Pada pukul 17:00 dari Gambar 2b,suhu udara dalam rumah jamur terdistribusi merata. Suhu udara rata-rata dalam rumah jamur $\left(28,14^{\circ} \mathrm{C}\right)$ lebih rendah daripada suhu udara lingkungan $\left(28,9^{\circ} \mathrm{C}\right)$. Pada Gambar $3 \mathrm{~b}$, suhu udara tertinggi berada di rak atas dan rak tengah berkisar $28,18^{\circ} \mathrm{C}-28,67$ ${ }^{\circ} \mathrm{C}$. Sebaliknya, suhu udara terendah berada di selatan dan utara rak yang kecepatan udaranya tinggi. Bertambahnya kecepatan udara atau aliran udara yang berhembus jika saluran yang dilalui terjadi penyempitan (kondisi tersebut berlaku Hukum Bernoulli). Pada pukul 17:00, RH udara ratarata dalam rumah jamur $(84,86 \%)$ lebih tinggi daripada $\mathrm{RH}$ udara lingkungan $(82,3 \%)$. RH udara tertinggi berada di rak bawah dengan nilai sebesar $86,90 \%$.

\section{Perbandingan Hasil Analisis CFD}

Hasil analisis CFD pada bangunan dengan evaporative cooler menggunakan air, suhu dan kelembaban udara mampu diturunkan sebesar $\pm 0,23^{\circ} \mathrm{C}$ dan $\mathrm{RH} \pm 2 \%$ (pukul 08:00); $\pm 1^{\circ} \mathrm{C}$ dan $\mathrm{RH} \pm 5,1 \%$ (pukul 12:00); $\pm 0,24^{\circ} \mathrm{C}$ dan $\mathrm{RH} \pm 10,1 \%$ (pukul 17:00). Hal ini menunjukkan bahwa proses evaporative cooling ini mampu menurunkan suhu udara dan menaikkan RH udara walaupun penurunannya kecil dan bisa diterapkan pada budidaya tanam jamur tiram yang membutuhkan suhu rendah dan kelembaban udara tinggi.

Evaporative cooling yang efektif untuk iklim panas dan kering, tidak efektif untuk iklim panas dan lembab. Sistem pendinginan ini mengandalkan perbedaan suhu bola kering dan bola basah, tetapi pada iklim tropika basah, perbedaan suhu bola basah dan bola kering sangat kecil, sehingga pendinginan udara melalui peningkatan kelembaban udara sampai mendekati jenuh sekalipun hanya menurunkan suhu sangat kecil (Suhardiyanto, 2009).

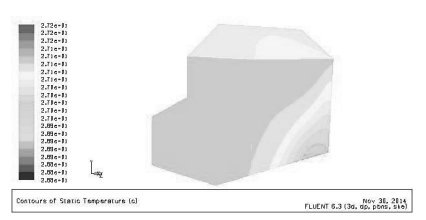

Pukul 08:00

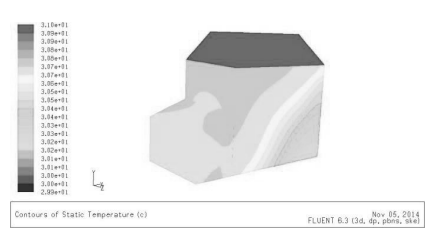

Pukul 12:00

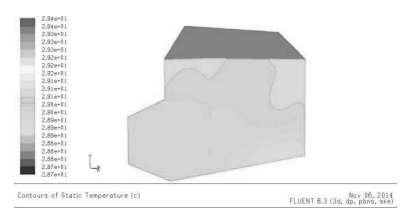

Pukul 17:00

a. Bangunan kontrol

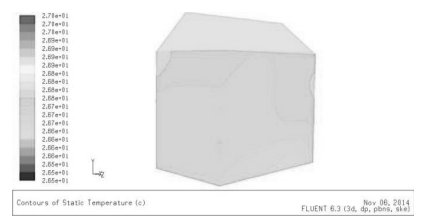

Pukul 08:00

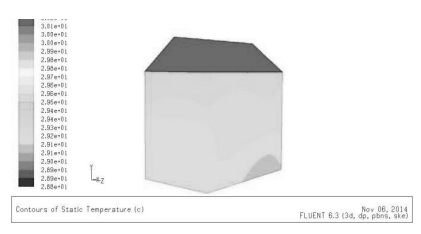

Pukul 12:00

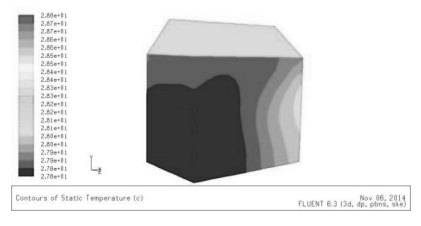

Pukul 17:00 b. Bangunan dengan evaporative cooler

Gambar 2. Sebaran suhu udara dalam rumah jamur pada: a. Bangunan kontrol; b. Bangunan dengan evaporative cooler menggunakan air pada pukul 08:00; 12:00; 17:00 WIB 


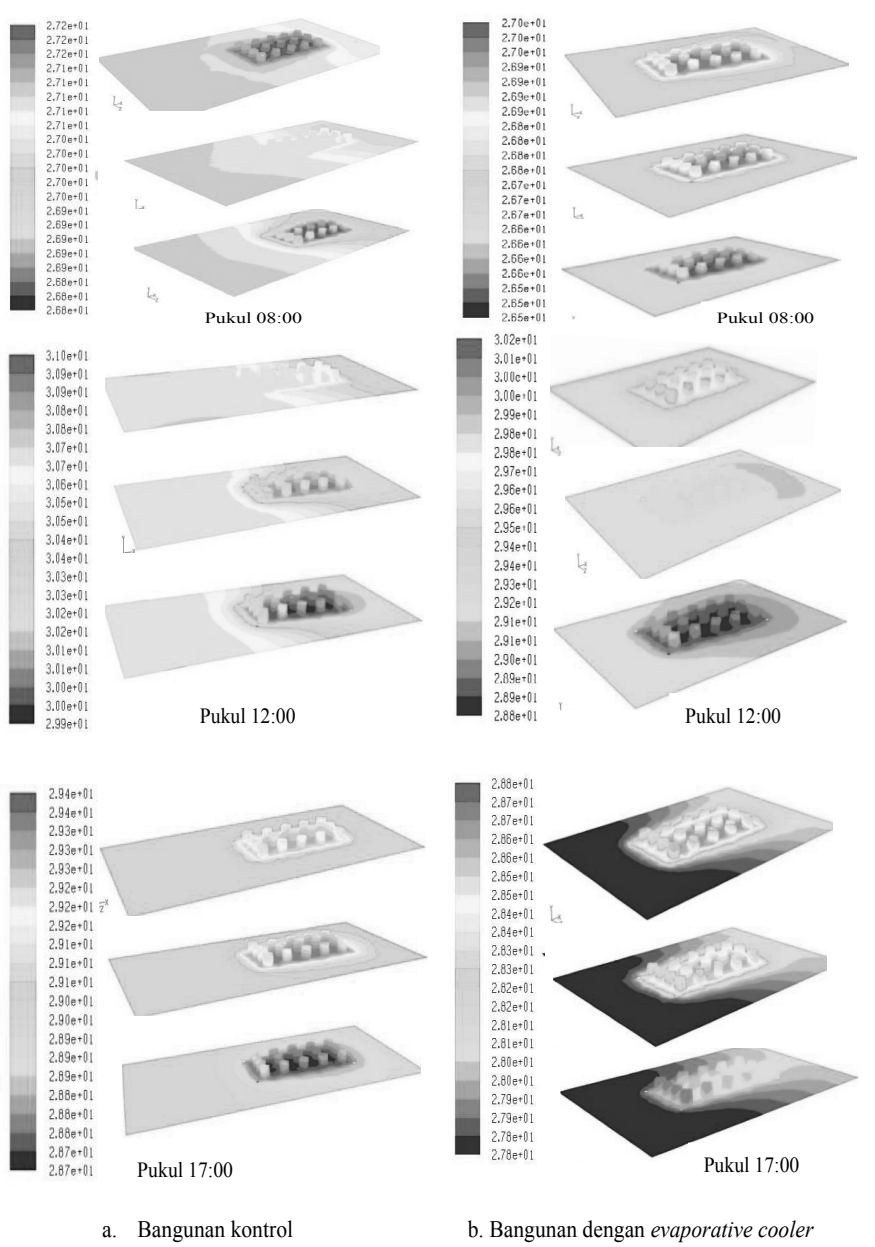

Gambar 3. Kontur suhu udara di rak-rak pada: a. Bangunan kontrol; b. Bangunan dengan evaporative cooler menggunakan air pada pukul 08:00; 12:00; 17:00 WIB

\section{Validasi}

Validasi distribusi suhu udara dilakukan dengan cara membandingkan data suhu hasil pengukuran dengan data suhu udara hasil CFD di 17 titik pengukuran. Hasil validasi distribusi suhu udara dalam ruang jamur menunjukkan kecenderungan hasil CFD mendekati hasil pengukuran dengan nilai error yang rendah. Nilai error suhu udara ratarata tertinggi pada bangunan kontrol (ventilasi alamiah)

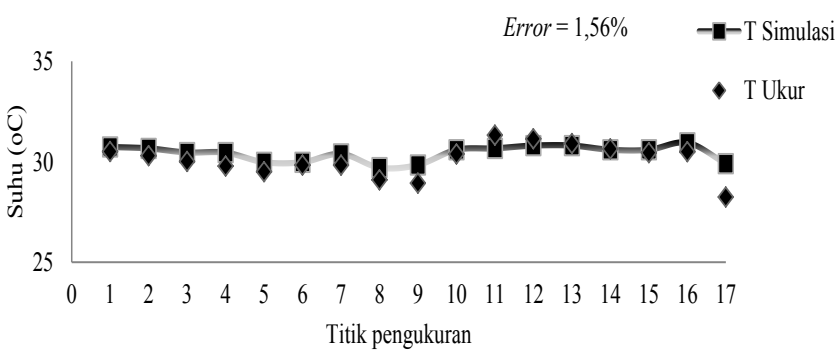

Gambar 4. Validasi suhu udara hasil CFD terhadap hasil pengukuran di 17 titik pada bangunan kontrol (pukul 12:00 WIB) sebesar 1,56\% (Gambar 4) dan 2,58\% pada bangunan dengan evaporative cooler menggunakan air (Gambar 5). Adapun, nilai error kelembaban udara rata-rata pada bangunan kontrol sebesar $1,54 \%$ dan $2,15 \%$ pada bangunan dengan evaporative cooler menggunakan air. Pada beberapa titik terjadi perbedaan yang cukup mencolok karena terkait dengan penentuan jarak grid yang sedikit berbeda antara pengukuran dan perhitungan CFD. Nilai error yang tinggi disebabkan oleh pembuatan geometri pada dinding rumah jamur diasumsikan tidak berlubang-lubang, tetapi dalam realitanya dinding rumah jamur yang berupa anyaman bambu memiliki lubang-lubang kecil yang memungkinkan tempat keluar masuknya udara luar sehingga menyebabkan error yang cukup besar, tetapi masih dalam batasan yang rendah.

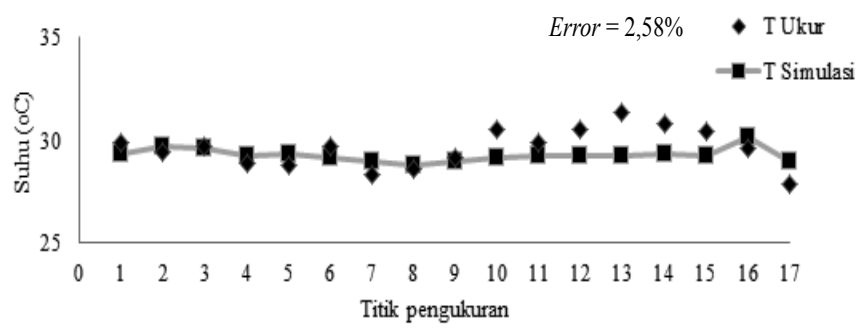

Keterangan:

1. Rak atas (depan) 7. Rak bawah (depan) 13.Dinding utara

2. Rak atas (tengah) 8. Rak bawah (tengah) 14. Outlet selatan

3. Rak atas (belakang) 9. Rak bawah (belakang) 15. Outlet utara

4. Rak tengah (depan) 10. Selatan rak 16. Atap

5. Rak tengah (tengah) 11. Utara rak 17. Lantai

6. Rak tengah (belakang) 12. Dinding selatan

Gambar 5. Validasi suhu udara hasil CFD terhadap hasil pengukuran di 17 titik pada bangunan dengan evaporative cooler menggunakan air (pukul 12:00 WIB)

Pada uji statistik paired sample t-test menggunakan data hasil pengukuran dan hasil perhitungan menggunakan CFD pada bangunan kontrol dan bangunan dengan evaporative cooler menggunakan air menunjukkan bahwa nilai $t$ hitung lebih kecil dari $t$ tabel dan nilai significant level lebih besar dari nilai $\alpha(0.05)$, sehingga dapat disimpulkan bahwa $\mathrm{H} 0$ diterima dan dinyatakan tidak ada perbedaan rataan secara signifikan antara hasil pengukuran dengan hasil CFD. Kesimpulan ini menunjukkan bahwa model perhitungan dengan CFD valid dan dapat digunakan sebagai representasi sistem dalam melakukan analisis terhadap model rumah jamur.

\section{KESIMPULAN}

Distribusi suhu udara dan kelembaban udara dalam rumah jamur dengan dua variasi perlakuan dapat dianalisis menggunakan Computational Fluid Dynamics (CFD) karena memiliki tingkat validasi cukup tinggi dengan nilai error 
suhu dan kelembaban udara rata-rata $1,56 \%$ pada bangunan kontrol dan 2,58\% pada bangunan dengan evaporative cooler menggunakan air. Hasil simulasi distribusi suhu pada ke dua perlakuan yang diberikan pada rumah jamur menunjukkan bahwa bangunan dengan evaporative cooler menggunakan air mampu menurunkan suhu udara dan meningkatkan kelembaban udara dalam rumah jamur dan memiliki hasil yang seragam dengan pola aliran udara yang terjadi dari inlet menuju outlet.

\section{UCAPAN TERIMA KASIH}

Ucapan terima kasih disampaikan kepada Sekolah Tinggi Pertanian (STIPER) Kutai Timur, Kalimantan Timur, atas bantuan dana penelitian sehingga penelitian bisa terlaksana dengan lancar. Tulisan ini adalah bagian penelitian tesis yang menggunakan dana penelitian tersebut. Dan ucapan terima kepada Fakultas Teknologi Pertanian, Universitas Gadjah Mada yang sudah memfasilitasi selama proses penelitian berlangsung.

\section{DAFTAR PUSTAKA}

Agromedia (2009). Jamur Konsumsi. PT Agro Media Pustaka, Jakarta.

Kibar. B. dan Peksen, A. (2008). Modelling the effects of temperature and light intensity on the Development and yield of different pleurotus species. Agricultura Tropica et Subtropica 41:2.

Han, J.H., Kwon, H.J., Yoon, J.Y., Kim, K., Nam, S.W. dan Son, J.E. (2009). Analysis of the thermal environment in a mushroom house using sensible heat balance and 3-D computational fluid dynamics. Biosystem Engineering 104: 417-424.
Kacira, M., Short, T.H. dan Stowell, R.R. (1998). A CFD evaluation of naturally ventilated, multi-span, sawtooth greenhouses.Transactions of The American Society of Agricultural Engineers 41: 833-836.

Patankar, S.V. (1980). Numerical Heat Transfer and Fluida Flow. Hemishpere Publishing Corporation. Mc-Graw Hill. New York.

Romdhonah, Y. (2011). Simulasi Distribusi Suhu dan Kelembaban Udara untuk Pengembangan Desain Rumah Tanaman di Daerah Tropika Basah. Tesis. Institut Pertanian Bogor, Bogor.

Singgih, M.L. dan Susanto, H. (2006). Perancangan model simulasi downtime machines untuk menentukan kecepatan mesin dan jumlah operator yang optimal pada divisi ring spinning. Prosiding Seminar Nasional Manajemen Teknologi IV. Magister Manajemen Teknologi. Institut Teknologi Sepuluh November, Surabaya.

Suhardiyanto, H. (2009). Teknologi Rumah Tanaman untuk Iklim Tropika Basah "Pemodelan dan Pengendalian Lingkungan". IPB Press, Bogor.

Tuakia, F. (2008). Dasar-Dasar CFD Menggunakan Fluent. Informatika, Bandung.

Yani, A. (2007). Distribusi Suhu dalam Kandang Sapi Menggunakan Computational Fluid Dynamics. Tesis. Institut Pertanian Bogor, Bogor.

Yanuati, I.N.T. (2007). Kajian Perbedaan Komposisi Media Tanam terhadap Pertumbuhan dan Hasil Jamur Tiram Putih (Pleurotus florida). Universitas Brawijaya, Malang.

Versteeg, H.K. dan Malalasekera, W. (1995). An Introduction to Computational Fluid Dynamics: The Finite Volume Method. Longman Scientific and Technical. New York. 